\title{
Constraints of Agricultural Input Supply and Its Impact on Small Scale Farming: The Case of Ambo District, West Shewa, Ethiopia
}

\author{
Tilahun Kenea ${ }^{1, ~ *, ~ A h i m e d ~ U m e r ~}{ }^{2}$, Zinabu Ambisa ${ }^{3}$ \\ ${ }^{1}$ Department of Agribusiness and Value Chain Management, College of Agriculture and Veterinary Science, Ambo University, Ambo, \\ Ethiopia \\ ${ }^{2}$ Department of Agribusiness and Value Chain Management, Mettu University, College of Agriculture and Forestry, Bedele, Ethiopia \\ ${ }^{3}$ Department of Agricultural Economics, Mettu University, College of Agriculture and Forestry, Bedele, Ethiopia
}

\section{Email address:}

tilahunkenea09@gmail.com (T. Kenea)

${ }^{*}$ Corresponding author

\section{To cite this article:}

Tilahun Kenea, Ahimed Umer, Zinabu Ambisa. Constraints of Agricultural Input Supply and Its Impact on Small Scale Farming: The Case of Ambo District, West Shewa, Ethiopia. International Journal of Agricultural Economics. Vol. 4, No. 2, 2019, pp. 80-86.

doi: $10.11648 /$ j.ijae.20190402.15

Received: February 17, 2019; Accepted: March 25, 2019; Published: April 29, 2019

\begin{abstract}
Agriculture is a principal economic activity mainly for those developing countries. This study was intended to analyze the impact of agricultural input supply on small scale farming in the study area; to examine the trends and forms of farming practiced by the farmers, to identify the farm input constraint existed in the study area, to assess input supply and its link with forms of farming. Both primary data and secondary were used for the study. In the survey three different forms of farming were identified. These are farmers who cultivate their own lands, rent out their land and rent in other's land. A formal and informal survey was conducted to gather information in Ambo district by using descriptive sampling techniques. The major output of the study indicates that agricultural input supply is poor in the study area. Moreover, input supply is influenced by major factors like input price, absence of input supply at the right time, credit constraint, farm size and annual income. Therefore, it is recommended that, improving the efficiency of credit system, timely and sufficient amount of delivering credit to farmers who engaged on crop production has to be considered, establishing efficient extension service in the study area is mandatory.
\end{abstract}

Keywords: Agriculture, GDP, Agricultural Input Supply, Forms of Farming, Input Constraint, Small Scale Farming, Formal and Informal Survey

\section{Introduction}

Agricultural productivity is one of the key determinant of high and sustained agricultural growth over the long term [3] However for developing countries agriculture is relative share to gross domestic product is smallest. But still supports this sector through subsidies, assigning effective farm land ownership rights, providing inputs to their small-scale farmers and facilitating agricultural markets $[12,13]$ but, in developed countries the realities reside on the reverse one. There exist institutional and economic constraints such as poor credit supply, market imperfections, excessive farm land fragmentation, etc and as a result agriculture remains less productive and most of the time at the subsistence level

In Ethiopia, around $94.4 \%$ of all farming is practiced by small scale rural peasant household farmers [6] such small scale farmers primarily produce for their subsistence and the size of their production unit is small [2].

Small scale rural household farmers are also exposed to shortage of food and other basic needs. The smallholder farmers, who are providing the major share of the agricultural output in the country, commonly employ backward production technology and limited modern inputs, given the growing land pressure and limit purchasing power of those small scale rural household farmers, a credit on farm inputs, 
like fertilizer and improved seeds, for the benefit of the resource poor farmers is critical to ensure the food security but when credits and resources are insufficient at all, small scale farmers may choose either to farm their land using less efficient method of production, or may decide to rent out their land to share croppers, or even may sell it for cash in partial or in total and finally will receive lower income from their land [23]

This trade off occurs most frequently in women headed households where resource constraints are greatest (agriculture and economic developments). In 1993, a nongovernmental organization introduced a new system of extension intervention aimed at increasing productivity and production of small holder farmers through an aggressive technology (mainly improved seeds and fertilizer) transfer program, and strengthening the linkage between the research and extension in order to streamline the process of technology generation and dissemination [24].

Male headed farmers have more access farm inputs capital better than female headed farmers [2], which confirms argument of [19]. Indeed, some argues that land farming in the form of share cropping is efficient, while some others against argument and said it is inefficient and is not a rational decision for the leasers (a Land owner who leases the land he possesses) and finally results in lower return to him. This is because the cultivator must repay part of the output to the leaser (landowner) and hence employ less labor and other farm inputs oriented in land.

In arguing for essentiality or credits, it is likely to cultivate extra farm land for share cropping or others forms by farmers who have access to more factors (oxen, labor, fertilizer, improved seed, etc), other who faced this factor constraints decided to lease or even sold their farmland to others. [4]

Specifically in Ambo most of small household have been faced input supply constraints for long time. So this constraint or idea put interest or motive the research to conduct the constraints of agricultural input supply and its impact on small scale farming. Farming is hardly possible without necessary inputs so farmer may decide not to farm his/her land if they faced a constraint. In the Ambo district small scale farmer didn't have enough input due to different constraint. Among the problem areas of small scale farmers in the Ambo district related to inputs specifically that all concerned bodies including researchers believe to exist includes; lack of focus of government for agricultural input supply, increased input price, credits constraints', family size, annual income, farmers cultural and willingness of farmers to accept and adopt new technologies.

A study of Ethiopian smallholders found that half of farmers surveyed for the study reported that fertilizer arrived after planting, while 32 percent reported Underweight bags, 25 percent complained of poor quality, and almost 40 percent reported that their planting was delayed by fertilizer problems [5]. Above mentioned problem areas were thoroughly studied both at Gosu kora and Bayo kurbi peasant associations to clearly identify the real constraints of agricultural input supply and its impact on small scale farming. So the aim of this paper was to identify the constraints of agricultural input supply, roles and its impact on small scale farming in the Ambo district by having the following specific objectives to:

(1) Identify the farm inputs constraints existed in the study area

(2) Assess the supply of inputs and the link it has with forms of farming

(3) Identify influential factors for the smooth functioning of input supply

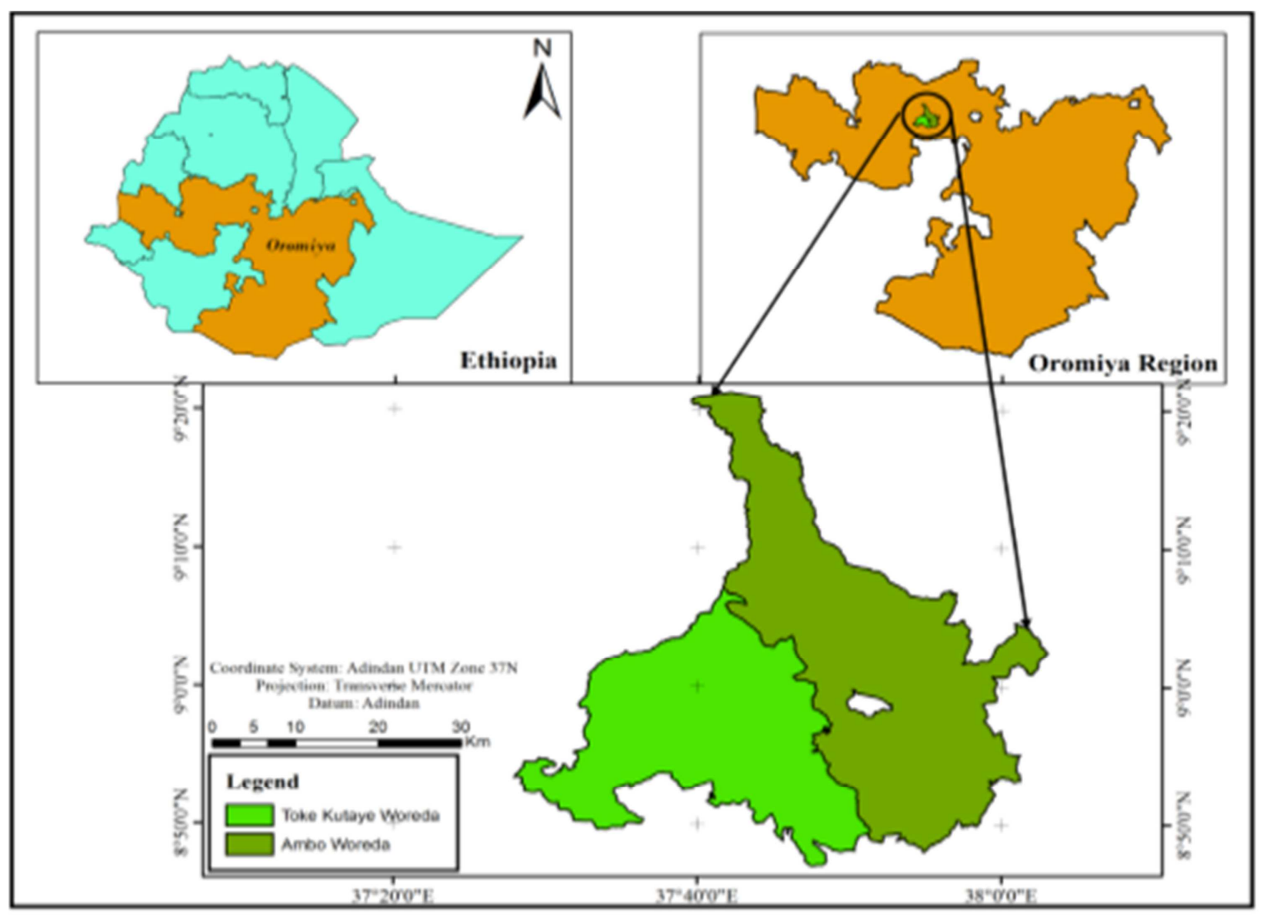

Figure 1. Map of the Study Areas (Source: College of Agriculture \& Veterinary Science GIS laboratory). 


\section{Methodology}

\subsection{Description of the Study Area}

This study was carried out in Ambo districts of West Shewa zone of Oromia National Regional State. Ambo district is situated at $8^{\circ} 56^{\prime} 30^{\prime \prime}-8^{\circ} 59^{\prime} 30^{\prime \prime} \mathrm{N}$ latitude and $37^{\circ}$ $47^{\prime} 30^{\prime \prime}-37^{\circ} 55^{\prime} 15^{\prime \prime}$ E longitude in central Oromia, Ethiopia, $110 \mathrm{~km}$ west of Addis Ababa. The district has 34 rural kebeles of which 23 of them are vegetable producers, and Ambo is the capital of the district. The 2007 national census reported total populations for this district is 108,406 , of whom 54,186 (49.98\%) were men and 54,220 (50.01\%) were women [6].

\subsection{Sampling Techniques and Procedures}

A formal and informal survey was conducted to gather information in Ambo districts by using multi stage proportional descriptive sampling techniques. Firstly the researcher would select purposively Ambo Woreda due to time and resource available. Then two kebele woud be selected purposively because most of small scale farmers who use input are found in this kebeles, thus information can easily found from the woreda agricultural office. Finally a total of 40 household respondents (proportionally from two kebele) are randomly selected at which the researcher would be considered as to collect information for questionnaire. This was due to the selected respondents were believed to be more experienced and knowledgeable about the problem.

\subsection{Method of Data Analysis}

In this study, descriptive statically tools are used to analyze the quantities data like means, percentages and frequencies qualitative, assessment mass carried out using key informants and focused group discussion, input supplies survey, farmers, DA's and government policy documents content analysis. Dependent variable of the study is agricultural inputs supply. For this study, independent variables were identified to influence the dependent variable. Independent variables that affect dependent variable include age, educational level, farm size credit services, annual income, Storage facility, distance from nearest input market, family labor, extension contact, type of road used, access to market- and input price- etc...

\subsection{Dependent Variables}

Dependent variable of the study is agricultural inputs supply index. The variable would operational zed as farmers' response in terms of the quantity of required and obtained inputs on the selected crops. It was measured using demandsupply index of the respondents with structured list of items selected.

$$
I S I=\frac{S x A / D x A+S x B / D x B+\operatorname{SxC} / D x C+\text { SyA } / D y A+\operatorname{SyB} / D y B+\operatorname{SyC} / D y C \ldots \ldots \ldots \ldots}{N}
$$

Where:

IDSI $=$ Input demand supply index

$\mathrm{S}=$ quantity of inputs supplied

$\mathrm{D}=$ quantity of inputs demanded/distributed/

A, B, C = Crops (teff, nug and lentil seed)

$\mathrm{x}, \mathrm{y} \ldots \ldots . . .=$ are types of inputs

$\mathrm{N}=$ number of inputs applicable

\section{Result and Discussion}

\subsection{Socio-Demographic Characteristics}

\subsubsection{Sex Structure of the Respondents}

Table 1. Age distribution of respondents.

\begin{tabular}{lll}
\hline Sex & Frequency & \% \\
\hline Male & 29 & 72.5 \\
Female & 11 & 27.5 \\
Total & 40 & 100.0 \\
\hline
\end{tabular}

Source: (Own survey result, 2016)

As shown from table 1, out of 40 respondent 29 are male and 11 are female. This corresponds to $72.5 \%$ are male and $27.5 \%$ are female respondents. As observed from the table, most male farmers are empower and participate in productive activities through delivering agricultural input so as to minimize vulnerability and improve their livelihood status.

\subsubsection{Educational Background of the Respondents}

Table 2. Educational status of respondents.

\begin{tabular}{lll}
\hline Educational status & Frequency & Percent \\
\hline Illiterate & 13 & 32.5 \\
Read and write & 10 & 25.0 \\
Primary school & 8 & 20.0 \\
Secondary school & 8 & 20.0 \\
Abovesecondary school & 1 & 2.5 \\
Total & 40 & 100 \\
\hline
\end{tabular}

Source: (computed from own survey data, 2016)

As shown from table 2, most of the respondents are illiterate. It can also be seen from the table that the decrease in the number of respondents with the increase in the educational status of the respondents. According to different sources and real world situations the researchers can conclude that the educational status or education level of the farmers were an important factor that affecting the probability of using agricultural inputs. The better the education level the farmer has the better will be his/her understanding concerning the knowledge of improved agricultural technologies. 


\subsubsection{Age Distribution of the Respondents}

Table 3. Age distribution of respondents.

\begin{tabular}{lll}
\hline Age & Frequency & Percent \\
\hline $20-30$ & 6 & 15.0 \\
$31-40$ & 17 & 42.5 \\
$41-50$ & 10 & 25.0 \\
$51-60$ & 5 & 12.5 \\
$>60$ & 2 & 5.0 \\
Total & 40 & 100 \\
\hline
\end{tabular}

Source: (computed from own survey data, 2016)

As it can be seen from table 3, above the largest and the smallest percentage of the respondents are in the age categories between31-40 and $>60$ respectively. The corresponding largest and smallest percentages of the respondents are $42.5 \%$ and $5 \%$ respectively. According to different sources and the real world situation, the age of farmers has negative effect on using agricultural inputs by contributing for risk aversion which confirms with our finding As the age of the farmers increases the demand for agricultural inputs will be decrease.

\subsubsection{Distribution of the Respondents by Land Size}

Table 4. Distribution of the respondents by land size.

\begin{tabular}{lllll}
\hline \multirow{2}{*}{ Landsize (ha) } & Male & \multicolumn{3}{c}{ Female } \\
\cline { 2 - 5 } & Frequency & $\mathbf{\%}$ & Frequency & \% \\
\hline$<0.5 \mathrm{ha}$ & 1 & 3.4 & 2 & 18.2 \\
$0.5-1$ ha & 14 & 48.3 & 2 & 18.2 \\
1-2ha & 12 & 41.4 & 6 & 54.5 \\
$>$ 2ha & 2 & 6.9 & 1 & 9.1 \\
Total & 29 & 100 & 11 & 100 \\
\hline
\end{tabular}

Source: (computed from own survey data, 2016)

As shown from table $4,1 \%$ of total respondent of male and $2 \%$ of total respondent of female have blow $0.5 \mathrm{ha}$ of farm land. From total respondents $48.3 \%$ of male and $2 \%$ of female are between 0.5 ha and 1 ha, and $41.4 \%$ of male respondents and $6 \%$ female respondents belong between 1 ha and 2 ha. The remaining $6.9 \%$ of male and $1 \%$ of female respondents have above 2 ha land size. From this, researchers can understand that most male and female headed farmers have between 0.5 ha and 1 ha of land. Therefore, the land size is an important factor in affecting the demand for agricultural inputs because the increase size of land holding provides sufficient income and there by funds for investment on modern farm inputs.

\subsubsection{Total Land per Each Category of Land Use Type}

Table 5. Total land per each category of land use type.

\begin{tabular}{lll}
\hline Land per category & Land size (ha) & Frequency \\
\hline Cultivated & 34.82 & 62.77 \\
Grazing & 1.75 & 3.15 \\
Perennial crop & 18.9 & 34.07 \\
Total & 55.47 & 100 \\
\hline
\end{tabular}

Source: (computed from own survey data, 2016)

The table 5, above is intended to describe the cultivated land of all respondents together in Gosu kora and Bayo kurbi Kebeles of Ambo district. As observed from the 34.82\% ha, $1.75 \%$ ha and $18.9 \%$ ha of land has cultivated, grazing and perennial crop respectively in all respondents together. Therefore, it indicates that land for cultivation is largest while grazing land is smallest.

\subsection{Forms and Trends of Farming (2005-2009)}

Forms and trends of farming in consecutive years imply farming through renting out of land, renting in of land, and own cultivation. It shows by whom the peasants plot is cultivated. Under renting in and renting out, both the owner and the share cropper obtained the portion of the yield, whereas under own cultivation the whole yield accrues to the land owner him/ herself. This implies that as far as getting the whole yield could be taken as better than getting the portion of the yield, it is preferable to the land owner, if he or she cultivates his/her farm land rather than renting out it. On the other hand, trend indicates change in extent of form of farming over cropping seasons.

Table 6. Forms and trends farming of all the respondents (2007-2011).

\begin{tabular}{|c|c|c|c|c|c|c|}
\hline \multirow{3}{*}{ Cropping seasons } & \multicolumn{6}{|c|}{ Forms and trends of farming (2007-2011) } \\
\hline & \multicolumn{2}{|c|}{ Cultivate own land } & \multicolumn{2}{|l|}{ Rent in } & \multicolumn{2}{|l|}{ Rent out } \\
\hline & Frequency & $\%$ & Frequency & $\%$ & Frequency & $\%$ \\
\hline 2007 & 26 & 65 & 6 & 15 & 8 & 20 \\
\hline 2008 & 21 & 52.5 & 9 & 22.5 & 10 & 25 \\
\hline 2009 & 18 & 45 & 10 & 25 & 12 & 30 \\
\hline 2010 & 12 & 30 & 9 & 22.5 & 19 & 47.5 \\
\hline 2011 & 11 & 27.5 & 7 & 17.5 & 22 & 55 \\
\hline
\end{tabular}

Source: (Own survey result, 2016)

Table 6 shows that, the trend and forms of farming were nearly stable over the whole cropping years with smaller variation in percentage except 2009/2010. Where the lowest percentage of the farmers cultivate their own land $30 \%$ and $27.5 \%$ respectively and the high percentage of the farmers rent out their lands $47.5 \%$ and $55 \%$ than the preceding cropping years because of the shortage of the supply of the agricultural inputs (fertilizers, improved seeds, chemicals and others) to the farm house holds. However, the extent of rent in had been following different path and shows larger difference when compared to own cultivation and renting out since the low income of farm house hold from cultivation of 
his/her own lands, he/she cannot rent in other lands or unable to pay for agricultural inputs supplied for that additional lands.

\subsection{Major Farm Input Problems of Farmers (2007-2011)}

When the respondents were asked, in order to know their response to input problems, $70 \%$ of the respondents have indicated the presence of input problem and 30\% indicated no problem,

Table 7. Farmers or respondents response to input problem in consecutive five years.

\begin{tabular}{lll}
\hline Response & Frequency & \% \\
\hline Yes & 28 & 70 \\
No & 12 & 30 \\
\hline
\end{tabular}

Source: (own field survey, 2016)

As shown in the above table 7, most farmers have input problems in consecutive year which corresponds $70 \%$. But, those respondents that have no input problems $(30 \%)$ use organic fertilizers on their farms.

\subsection{Input Problems (2007-2011)}

The result of this study obviously shows that, farmers have limited access to farm inputs in many ways. The input problems identified in this research are fertilizer, improved seed and chemicals (2007-2011) (table 8). These input problems are decisive and influence farmers decision to, or not to cultivate their land. When farmers are actually with insufficient farm inputs or with no inputs at all, they usually decide to rent out their own lands.

Table 8. Distribution of input problems from (2007-2011).

\begin{tabular}{llllll}
\hline \multirow{2}{*}{ Input problem } & \multicolumn{6}{l}{ Input problems in consecutive years } \\
\cline { 2 - 6 } & $\mathbf{2 0 0 7}$ & $\mathbf{2 0 0 8}$ & $\mathbf{2 0 0 9}$ & $\mathbf{2 0 1 0}$ & $\mathbf{2 0 1 1}$ \\
\hline Fertilizer & $12(25)$ & $15(37.5)$ & $17(53.1)$ & $25(71.4)$ & $28(77.8)$ \\
Improved seed & $19(39.6)$ & $15(37.5)$ & $12(37.5)$ & $10(28.6)$ & $8(22.2)$ \\
Chemicals & $17(35.4)$ & $10(25)$ & $3(9.4)$ & $0(0)$ & $0(0)$ \\
\hline
\end{tabular}

Source: (Own survey result, 2016)

NB: The number in the bracket shows the percentage of the respondents that have indicated the problems in each cropping years.

From the table 8 above, researchers can summarize that fertilizer problems in consecutive five years are increased at increasing rate as the respondent have indicated (this arises from price rise, credit constraint, shortage in supply and lack of the resource by the farm HHs) and improved seed problems are varied in small scales (since the farmers does not use it more, its problem is nearly constant). While the chemical problems are decreased at decreasing rate and become Zero in year 2010/2011. The related problems to this all input problems are shortage of supply, credit constrain, increase in price of that inputs, post phone in time of supply (not supplied on time) etc, throughout the consecutive cropping years. From this the researches can conclude that the fertilizer problem is the serious problems to the farmers of the Gosu kora and Bayo kurbi kebeles of
Ambo woreda.

\subsection{The Relationship Between Agricultural Input Supply and Forms of Farming}

The trends and form of farming practiced by the farmers are influenced by the supply of agricultural inputs like, fertilizer, improved seed, Chemicals and others to the farms households. As it is presented under section 4.4 above, there is variation in forms of farming over cropping years. The larger difference in the extent of rent in when compared to own cultivation and rent out since the low income of farm house hold from cultivation of his/her own lands, he/she cannot rent-in other lands or unable to pay for agricultural input supplied for that additional lands.

\subsection{Uses of Agricultural Inputs by Farmers}

It is known that ownership ( access) of the a farm house hold to farm inputs like land, improved seed, fertilizer, oxen, chemicals have significant and determining role in influencing productivity and profitability of small scale farmers. Therefore, to determine whether the household heads or respondents use agricultural inputs or not on their farming land, researchers have asked the question of do you use farm input and the result of response to this question is presented in tables 8 below.

Table 9. Use of agricultural input by farmers.

\begin{tabular}{lllll}
\hline \multirow{2}{*}{ Response } & Male & \multicolumn{3}{c}{ Female } \\
\cline { 2 - 5 } & Frequency & \% & Frequency & \% \\
\hline Yes & 25 & 72.4 & 6 & 54.5 \\
No & 4 & 27.6 & 5 & 45.5 \\
Total & 29 & 100 & 11 & 100 \\
\hline
\end{tabular}

Source: own field survey, 2016

As shown in above table, most of male household heads use agricultural input on their lands while some of them did not use farm input on field. It corresponds to $72.4 \%$ and $27.6 \%$ respectively. On the side of women, it is also true that most female household heads use agricultural input on their farm but, some of them did not use farm inputs on their farm land. It corresponds to $54.5 \%$ and $45.5 \%$ respectively. Therefore, it is possible to conclude that most small scale farmers in the Gosu kora and Bayo kurbi kebeles of Ambo woreda use agricultural (farm) inputs such as chemical (pesticide, herbicide), fertilizer, improved seed, and others on their field.

\subsection{Impact of Agricultural Inputs on Small Scale Farming}

As discussed in the above parts of the research, most of household head in Gosu kora and Bayo kurbi kebeles are users of agricultural inputs on their farm land. As the farmers respondents have indicated the impacts or results of farm inputs are good related with the availability of natural rainfall. Before they started to use farm inputs the production, productivity and profitability of their farm lands was very low. But, as soon as, they started to use agricultural 
inputs, the production, productivity, efficiency and profitability of their farm lands increased along with as responded by most farm households.

However, some HHHs responded that the use of agricultural inputs on grazing land is associated with negative impacts. When chemicals are applied on grazing land, their cattle and oxen are affected as responded by some of them.

\subsection{Source of Land for the Ownership}

The concept of this part in our research is related to either the land for the farmer is from gift, rent in or rent out.

Table 10. Source of land for the ownership.

\begin{tabular}{lllll}
\hline Sourceof & Male & \multicolumn{3}{c}{ Female } \\
\cline { 2 - 5 } land & Frequency & $\mathbf{\%}$ & Frequency & \% \\
\hline Gift & 22 & 75.9 & 8 & 72.7 \\
Rent in & 3 & 10.3 & 1 & 9.1 \\
Rent out & 4 & 13.8 & 2 & 18.2 \\
\hline
\end{tabular}

Source: own field survey, 2016

As shown in the table 10 above, the source of land to male and female house hold is mostly from gift. However, there is also rent in and rent out some extent. It corresponds to $75.9 \%$ gift, $10.3 \%$ rent in and $13.8 \%$ rent out for male and $72.7 \%$ gift, $9.1 \%$ rent in and $18.2 \%$ rent out for female household head respectively. Therefore, researches can conclude that the source of land owner ship for household head in Gosu kora and Bayo kurbi kebeles of Ambo woreda is almost gift from their family (from their ancestor).

\subsection{Source of Income for the Farmers}

This concept is related to whether income of the household heads is obtained from agricultural activities or other nonfarm activities.

As our survey result indicated the major source of incomes to the scale farm house hold heads in Gosu kora and Bayo kurbi kebeles of Ambo woreda is agriclultural activities, and relatively low from practicing non-farming activities.

\section{Conclusion and Recommendation}

\subsection{Conclusion}

Agriculture is a principal economic activity mainly for those developing countries.

Agricultural inputs like improved seed, fertilizer, pesticide, chemicals, improves farm tools, etc supply in line with efficient extension services would lead to ensure enhanced production and productivity provision of input timely and according as to the demand of beneficiaries is crucial to boost up production of small holder farmers. However, the supply of these production enhancing inputs and service were constrained it various factors. These factors are shortage of supply, credit constraint, increased price of input, and time of supply etc greatly affected the production of the farmers. It also tried to investigate, the forms of farming practiced by the farmers over cropping season, the farm input constraints existed in the farmers, the supply of input and the link it has with form of farming. For this purpose, primary data source that were obtained in 2015 from 40 farmers living Ambo district and secondary data were used. In this study, descriptive statistical tools were used to analyze the quantitative data like means, percentages and frequencies. Qualitative assessment was carried out using key informants and focused group discussion with input suppliers, farmers, DA'S and government policy document content analysis for secondary data. In the survey three different form of farming are identified. These are farmers who cultivate their own lands, rent out their land and rent in others' land. The source of income for small scale farmers in the study area were only from agricultural activities. That means there is no habit of practicing non farming activity as a source of income.

\subsection{Recommendation}

Researchers who participate in this well organized research work are highly egger to recommend different bodies that are engaged in constraint of agricultural input supply and its impact on small scale farming sector particularly in Ambo district, based on results and observed situation so:-

(1) An input problem, particularly fertilizer is a serious problem to the farmers of the Amob woreda. Therefore, government, NGOs and other bodies should tackle these problems in order to increase the agricultural productivity of farm house hold heads.

(2) Improving the efficiency of credit system, timely and sufficient amount of delivering credit to farmers who engaged on crop production has to be considered.

(3) Attention has to be given women farmers group to empower them and participate in productive activities to minimize vulnerability and improve their livelihood status.

(4) Establishing efficient extension service in the study area is mandatory.

(5) Attention has to be given by local administration to rural development and agricultural extension activates.

As non-farm income was found to be the most important factor associated with owner cultivation, motivation for farmers to engage in non-crop farm activities such as petty trade, craft and cottages like pottery, weaving, simple metal work should be facilitated by the concerned bodies so that they help reducing farmers farm input constraints.

\section{Conflicts of Interests}

The authors have not declared any conflict of interests.

\section{Acknowledgements}

Before and above all, I would like to thank God, the almighty, who has given me the strength, health, and know how to complete this work.

I am very much grateful to my advisor Mr Chalchisa Fana, Who played a decisive role in my academic and professional 
development. His continuous advice, guidance, and valuable suggestions as well as his unreserved encouragement in providing the directions to work hard broaden my views and expanded my interests. And also I would like to extend my heart gratitude and sincere appreciation to Ambo University and Ambo Agriclture office. Finally I owe a lot to my parents, Mr Kenea Tiba and Birhane Bekele for their unreserved support and cooperation they rendered for me to continue the study at Ambo University.

\section{References}

[1] Abadi, A. K. and D. J., Pannell, 1999. A conceptual frame work of adoption of an Abadi, A. K. and D. J., Pannell, 1999. A conceptual frame work of adoption of an agriculturalInnovation. J. Agricultural Economics, University of Western Australia, Perth. 2(9):145-154.

[2] Abar Suleiman (2004), Supply response and Gender in Ethiopia, Sheffield university, Sheffield "Agriculture and economic development".

[3] Adeleke S., Abdul B. K., and Zuzana B., 2009. Smallholder Agriculture in East Africa: Trends, Constraints and Opportunities, ADBG (African Development Bank Group), Working paper Series No.105, April, 2010.

[4] Bereket K. (1995) "the nature of share -cropping in Ethiopia; some preliminary observations Addis Ababa University.

[5] Bonger, Tenkir, Gezahegn and Tadese Agriculturural extension, adoption and diffusionin Ethiopia, research report I, Ethiopian Development Research Institute, Addis Abeba,2004.

[6] CSA (Central Statistical Authority) (2007). Summary and Statistical Report of 2007 Population and Housing Census. Federal Democratic Republic of Ethiopia Population and Census Commission.

[7] FAO, (2008), Global information and early warning system on food and agriculture world food program.

[8] Getahun D. 2004. Assessment of Factors Affecting Adoption of Wheat Technologies and Its Impact. The Case of Hula District, Ethiopia. M. Sc. Thesis (Unpublished) Presented to School of Graduate Studies of Alemaya University, Ethiopia.

[9] Getahun D., M. Mwangi, H. Verkuijil and Wondimu A. 2000. An assesement of the adoption of seed and fertilizer packages and the role of credit in smallholder maize production in Sidama andNorth Omo Zones, Ethiopia. EARO, CIMMYT, November 2000. p.24.

[10] GirmaTaye (1999), Adoption of improve bread wheat varieties and inorganic fertilizer by small -scale farmers: in Yelmana Densa and Farta Districts of north Ethiopia.
[11] Haji Bi u, 2003. Adoption of cross bred Dairy Cows in Arsi Zone. The case of Tiyo and Lemu Bilbilo woredas. M. Sc. Thesis (Unpublished) Presented to School of Graduate Studies of Alemaya University, Ethiopia

[12] Hussein (2008), 'influence of credit constraints on production efficiency': the case of south eastern Ethiopia. Department of economics, Swedish university of agricultural science.

[13] (Jack Thurston, 2008: Deininger, 2003, Bhaduri, 2000). Ministry of agriculture, fishies and food forum 1990 to 2001.

[14] Keith kriffen, Agrarian policy; the political and economic context, world development November, 1973.

[15] Legesse, D. (2001). Empirical analysis of duration of herbicide adoption in teff- based farming system of West Shewa Zone, Ethiopia. J. of Agricultural Economics. 5(142): 1-22, Feb.2001.

[16] Miemael P. Todaro (2000)'development economics' seventh edition, new York university.

[17] Nkonya, E., T. Schroeder and D. Norman, 1997. Factors affecting adoption of improved maize seed and fertilizer in Northern Tanzania, 48(1): 1-12.

[18] Rahmeto, N. (2007), 'determinants of adaptation of improved haricot bean production packages in Alaba special Woreda

[19] Roy, B. C., T. S. Bhogal and L. R. Singn, 1999. Tenancy and adoption of new farm technology: A study in West Bengal, India. Bangladesh Journal Economics. xxii 1(1999):39-49.

[20] Sasakawa Global 2000, SG-2000/Ethiopia Project: Activities and outputs:- An assessment- 19932001, SG-2000, 2002, Addis Ababa.

[21] Spielman, D. J., 2005. Systems of innovation: Models, methods, and future directions. Innovation Strategy Today 2(1):55-56. agriculturalInnovation. J. Agricultural Economics, University of Western Australia, Perth. 2(9):145-154.

[22] Tesfaye Zegeye and Shiferaw Tesfaye, 2001. Determinants of adoption of improved maize technologies and inorganic fertilizer in Southern Ethiopia. Research Report No. 39. Ethiopia Agricultural Research Organization (EARO).54p.

[23] WB (World Bank) (2011). Maize Revolutions in SubSaharan Africa: Policy Research Working Paper. Agriculture and Rural Development Team, NewYork

[24] Wolday Amha, 1999. "Improved seed marketing and adoption in Ethiopia". Ethiopian journal of Agricultural Economics, AESE, Addis Ababa, Ethiopia vol. 3 No 1 - pp 41-88. 